medRxiv preprint doi: https://doi.org/10.1101/2021.08.12.21261986; this version posted August 13, 2021. The copyright holder for this preprint

(which was not certified by peer review) is the author/funder, who has granted medRxiv a license to display the preprint in perpetuity.

It is made available under a CC-BY-NC 4.0 International license .

\title{
Plasmodium falciparum malaria during pregnancy: the impact of parasitaemia and
}

\section{anaemia on birthweight.}

Dawood Ackom Abbas ${ }^{\mathrm{a}}$, Abdul-Hakim Mutala ${ }^{\mathrm{a}}$, Samuel Kekeli Agordzo ${ }^{\mathrm{a}}$, Christian Kwasi

Owusu $^{\mathrm{b}}$, Bernard Walter Lartekwei Lawson ${ }^{\mathrm{a}}$ Kingsley Badu, ${ }^{\mathrm{a}, \text {, }}$,

${ }^{a}$ Department of Theoretical and Applied Biology, Kwame Nkrumah University of Science

and Technology, Kumasi, Ghana

${ }^{\mathrm{b}}$ Kumasi Center for Collaborative Research for Tropical Medicine, Kwame Nkrumah

University of Science and Technology, Kumasi, Ashanti, Ghana

*Corresponding author: kingsbadu@gmail.com / www.vectorgenes.com

\begin{abstract}
Malaria in pregnancy remains a major problem of public health concern in Sub-Saharan Africa due to its endemicity and the diverse consequences on both the mother and the baby. Much attention, therefore, is needed to fully understand the epidemiology of the disease and to mitigate the devastating outcomes. The present study aimed at investigating malaria in pregnancy, its adverse effects on pregnant women and the impact on birthweight of babies. A total of 222 pregnant women gave their consent and were recruited into the study during their routine Antenatal care visits. This study employed a combination of cross-sectional and longitudinal cohort study designs. For 122 women in the cross-sectional arm, blood samples and data were obtained once, whilst 100 women in the longitudinal cohort arm were followed up from recruitment until delivery. Demographic information, obstetric history and risk factors were obtained by administering questionnaires. About $1.0 \mathrm{ml}$ of venous blood was drawn to determine malaria parasitaemia and anaemia status of the participants. The birthweights of the babies were also taken at delivery. The prevalence of malaria and anaemia was $19.8 \%$ and $27.0 \%$ respectively at registration for all 222 participants. All infections were P. falciparum malaria. One hundred and forty-six (65.8\%) of participants had ITN but only $72(32.4 \%)$ used it the previous night. Young age and rural settings were risk factors for malaria. Young age and malaria positive pregnant women had increased risk of anaemia. In the follow-up group which ended with 54 participants, the overall prevalence of malaria and anaemia were $18.7 \%$ and $32.4 \%$ respectively. Fifty-two $(96.3 \%)$ of pregnant women attended ANC $\geq 4$ times and $55.6 \%$ took $\geq 3$ doses of SP. There were two cases of miscarriage. Low birthweight occurred in $5.6 \%$ of babies. Both malaria and anaemia during pregnancy had no significant impact on birthweight of the babies. Although few of the babies had low birthweight, this number can be further reduced when pregnant women attend ANC and take $\mathrm{SP}$ at the recommended number of times.
\end{abstract}

Keywords: pregnant women, malaria, anaemia, low birthweight, Sulphadoxine-

pyrimethamine, Ghana

NOTE: This preprint reports new research that has not been certified by peer review and should not be used to guide clinical practice. 


\section{Introduction}

About $90 \%$ of the global malaria cases occur in Sub-Saharan Africa including Ghana, with an estimated 25 million women predisposed to the risks posed by the infection and its accompanying adverse consequences during pregnancy (Ibrahim et al., 2017). In Ghana, there is an estimated 3.2 million malaria cases leading to about 38,000 deaths every year (Owusu Adjah and Panayiotou, 2014). It accounts for more than $44 \%$ of outpatient department attendance of which an estimated $13.8 \%$ are represented by pregnant women resulting in $9.4 \%$ of all maternal deaths (Orish et al., 2015; Owusu-Agyei et al., 2007; Saaka et al., 2009). Malaria is also a major contributor to the neonatal mortality rate in Ghana, standing at 29 per 1,000 deaths (Ghana Health Service, 2021).

In view of this, the World Health Organization (WHO) promotes a multi-pronged approach to malaria control during pregnancy. This involves the provision of intermittent preventive treatment with sulphadoxine-pyrimethamine (IPT-SP), use of insecticide treated nets (ITN) and effective case management of confirmed infections (WHO, 2014).

These strategies coupled with other efforts should see a huge reduction in the burden of the infection, however, this is not the case in Ghana. The prevalence of anaemia and malaria, especially asymptomatic malaria, and their deleterious effects during pregnancy continue to be of public health concern in the country. Even though antenatal care attendance in many health facilities in Ghana have seen an increase with the implementation of these strategies, the maternal mortality rate is approximately 308 per 100,000 live births (WHO et al., 2019).

A study conducted in the Ashanti region found a prevalence of $12.6 \%$ and $62.6 \%$ of malaria and anaemia respectively in pregnant women (Tay et al., 2013). A previous study also recorded a $15 \%$ prevalence of the infection among pregnant women in the same region (Tutu 
et al., 2011a). Other studies also reported more anaemia cases in urban settings compared to rural settings (Iqbal et al., 2016). These results emphasize the need to investigate the underlying cause of the infection amidst the several control measures. Studies conducted in the region are mostly cross-sectional, examining malaria and its associated anaemia among pregnant women. A longitudinal study is therefore needed to investigate the intensity of the infection and its consequence during the gestation period and the ultimate outcome.

The present study thus sought to investigate the burden of malaria during pregnancy, its adverse effects on the pregnant women and the impact on birth outcome and some factors that influence the infection prevention and control.

\section{Methods}

\subsection{Study areas}

The study was carried out in four health facilities namely: the University (KNUST) Hospital, Aniniwah Medical Centre (Emena), Kuntanase Government Hospital and Agona Government Hospital, all in the Ashanti region of Ghana from February to December 2018.

The University (KNUST) Hospital and Aniniwah Medical Centre (Emena) are located in Kumasi in the Oforikrom Municipality. Kuntanase Government Hospital is located in Kuntanase which is the capital of the Bosomtwe district; the Agona Government Hospital is located in Agona, the capital of Sekyere-South district. Both Kuntanase Government Hospital and Agona Government Hospital serve as the health care centres to their respective towns and the nearby towns and villages within their districts.

\subsection{Ethical consideration}


Prior to the commencement of this study, ethical approval was obtained from the Committee on Human Research Publications and Ethics (CHRPE) of the School of Medical Sciences, Kwame Nkrumah University of Science and Technology (KNUST), and Komfo Anokye Teaching Hospital (Ref: CHRPE/AP/544/18). All the study participants signed informed consent forms after the study goals were thoroughly explained to them in the local language, where required.

\subsection{Study design and patients}

The study population were pregnant women seeking antenatal care either for the first time or were present for their routine monthly visits. Two hundred and twenty-two (222) participants were recruited at enrolment out of which 100 of them were selected for follow up till delivery. Inclusion criteria were: informed consent, no critical illness and additionally, delivery at the hospital for the follow-up group. Demographic information, the use of preventive measures and obstetric history were taken through questionnaire administration. The malaria and anaemia status of all participants recruited were determined. For the followup group, malaria and anaemia status were determined for a maximum of 3 times till delivery to coincide with their scheduled visits at the ANC centre. Birthweight record of babies was taken at delivery.

\subsection{Sample collection and examination}

About $1.0 \mathrm{ml}$ of venous blood samples were taken by a trained phlebotomist using sterile syringes and needles and transferred into well labelled EDTA tubes. Each blood sample was screened for malaria parasites using RDT and microscopy, and their haemoglobin concentration (anaemia status) was determined using Sysmex XP-300.

Thick smears of the blood samples were prepared, stained with $10 \%$ Giemsa solution for 15 minutes and examined under the microscope (x100 objective lens) for the presence of malaria 
medRxiv preprint doi: https://doi.org/10.1101/2021.08.12.21261986; this version posted August 13, 2021. The copyright holder for this preprint (which was not certified by peer review) is the author/funder, who has granted medRxiv a license to display the preprint in perpetuity.

It is made available under a CC-BY-NC 4.0 International license .

parasites. The parasites were quantified by counting parasites against white blood cells (WBC). Depending on the number of parasites present, the parasites were counted against 200 or 500 white blood cells. A blood film is declared negative when no parasite was seen after 100 high power fields have been viewed (WHO, 2010).

Full blood counts were done to estimate the haemoglobin concentration of the blood samples using the Sysmex XP-300 automated haematology analyser. Concentrations lesser than 11 $\mathrm{g} / \mathrm{dl}$ were reported as anaemic (WHO, 2001).

Data on ANC visits, SP taken, and birth weights of babies were taken from the delivery records for women who were involved in the follow up. Birth weights $<2.5 \mathrm{~kg}$ were considered low and weights $>2.5 \mathrm{~kg}$ but less than $4.0 \mathrm{~kg}$ were considered normal (WHO, 2016).

\subsection{Data analysis}

Data collected were coded and entered into Microsoft Office Excel 2016. The data was then analysed using Microsoft Office Excel 2016 and SPSS version 23 software packages.

Tables showing percentages were provided for categorical variables and compared using the Pearson's Chi-square test. Means and standard deviations were provided for continuous variables. Binary logistic regression was used to analyse the strength of association of dependent variables with malaria, anaemia, and low birthweight. Mann Whitney U test and Kruskal Wallis tests were used to compare non-parametric variables where applicable. For all tests, $\mathrm{p}$ values less than 0.05 were considered statistically significant.

\subsection{Results}

\subsection{Maternal characteristics of participants}


Overall, 222 pregnant women were recruited for the study with a mean age of 28.2 years. As shown in Table 1 below, majority of the participants were above 20 years old and multigravidae. Most of them were in their $2^{\text {nd }}$ trimester, possessed ITN and had not taken IPT-SP.

Table 1. Maternal characteristics of participants recruited for the study

\begin{tabular}{ll}
\hline Characteristics & N $(\%)$ \\
\hline Total & $222(100)$ \\
Hospital & \\
$\quad$ University (KNUST) & $71(32.0)$ \\
Aniniwah (Emena) & $52(23.4)$ \\
Kuntanase & $42(18.9)$ \\
Agona & $57(25.7)$ \\
Age (years) & \\
Mean \pm SD & $28.2 \pm 6.3$ \\
$\quad<20$ (Adolescent) & $21(9.5)$ \\
$\geq 20$ (Old) & $201(90.5)$ \\
Gravidity & \\
Primigravida & $82(36.9)$ \\
Multigravida & $140(63.1)$ \\
Gestational period & \\
$1^{\text {st }}$ trimester & $80(36.0)$ \\
$2^{\text {nd }}$ trimester & $105(47.3)$ \\
$3^{\text {rd }}$ trimester & $37(16.7)$ \\
IPT-SP Usage & \\
Yes & $62(27.9)$ \\
No & $160(72.1)$ \\
ITN possession and usage & \\
Yes & $146(65.8)$ \\
No & $76(34.2)$ \\
Sleep under previous night & $72(32.4)$ \\
\hline
\end{tabular}

\subsection{Prevalence of malaria and anaemia}

The overall prevalence of malaria and anaemia at enrolment were $19.8 \%$ and $27.0 \%$ respectively. All recorded malaria infections were caused by P. falciparum.

\subsubsection{Hospital based prevalence}


The highest malaria prevalence of $26.3 \%$ was recorded at the Agona Government hospital whereas Aniniwah Medical Centre (Emena) recorded the highest for anaemia prevalence of 40.4\%. The least malaria and anaemia prevalence of $7.0 \%$ and $9.9 \%$ respectively were recorded at the University hospital (Fig 1). Pregnant women from Kuntanase and Agona government hospitals were found to be at higher risk of infection (Table 3). Additionally, participants with malaria had increased risk of being anaemic (OR=4.733 95\% CI 2.3579.504, p<0.001) (Table 3).

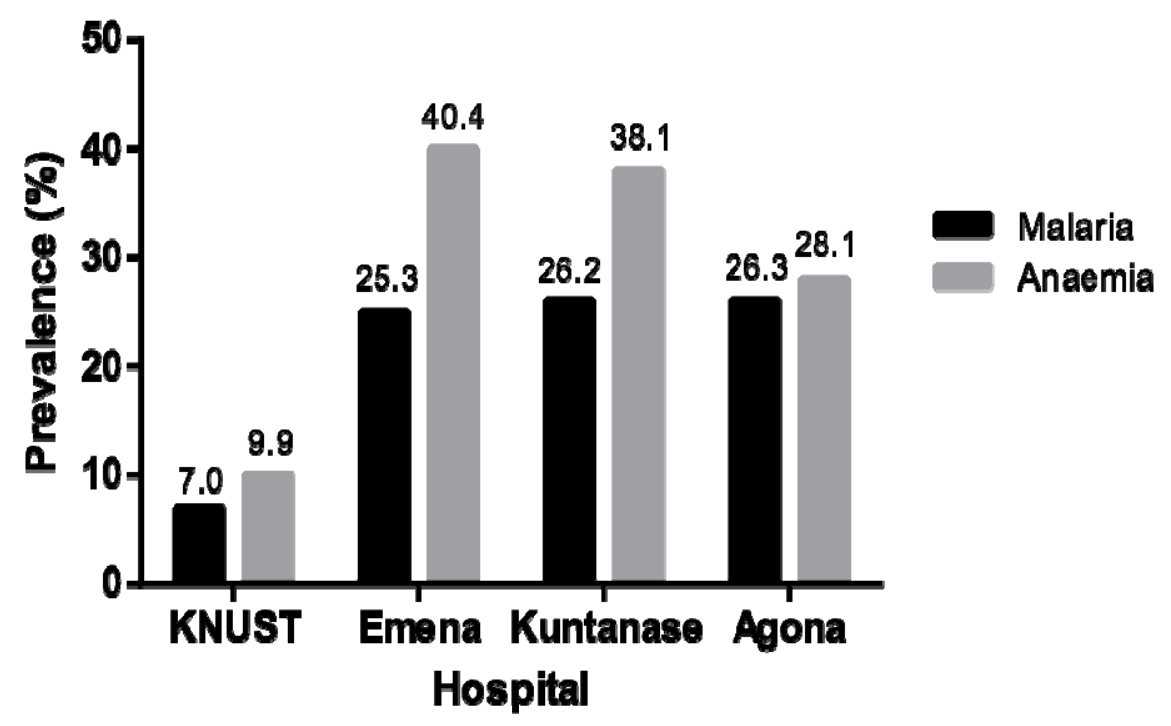

Fig 1. Prevalence of malaria and anaemia in the various hospitals

\subsubsection{Age prevalence}

The age range of all the participants was between 15 and 45 years with a mean age of $28.2 \pm$ 6.3 years. This was further categorized into two; young (adolescent) and old, i.e. below twenty (20) years of age, and twenty and above $(\geq 20)$ respectively. Among the age groups, malaria prevalence was higher $(38.1 \%)$ in those aged $<20$ compared to $17.9 \%$ in pregnant women aged $\geq 20$. Anaemia was also more prevalent amongst young pregnant women than in 
medRxiv preprint doi: https://doi.org/10.1101/2021.08.12.21261986; this version posted August 13, 2021. The copyright holder for this preprint (which was not certified by peer review) is the author/funder, who has granted medRxiv a license to display the preprint in perpetuity.

It is made available under a CC-BY-NC 4.0 International license .

the older women, $10(47.6 \%)$ and $50(24.9 \%)$ respectively. Pregnant women aged less than 20 had increased odds of both malaria and anaemia (Table 3).

\subsubsection{Gravidity and gestational prevalence}

Primigravida women were eighty-two (36.9\%) whilst multigravida women were one hundred and forty $(63.1 \%)$. Twenty-one $(25.6 \%)$ of primigravida women and twenty-three $(16.4 \%)$ of multigravida women had malaria parasitaemia. Anaemia prevalence was $31.7 \%$ in primigravida women and $24.3 \%$ in multigravida women (Table 3 ).

Based on their gestational period, $80(36.0 \%)$ women were in their first trimester, 105 $(47.3 \%)$ in the second trimester and $37(16.7 \%)$ in their third trimester. More than half (61.4\%) of the participants who tested positive for malaria were in their second trimester with the least recorded in women who were in their first trimester (18.2\%). Anaemia prevalence was $35.1 \%$ in third trimester, $28.6 \%$ in second trimester and $21.3 \%$ in first trimester (Table $3)$.

\subsubsection{Prevalence of malaria and anaemia according to the use of preventive measures}

As part of their routine ANC visits, pregnant women are given insecticide treated nets (ITNs) during registration and monthly Sulphadoxine-pyrimethamine (SP) as intermittent preventive treatment (IPT).

Sixty-two (27.9\%) participants admitted to having taken SP during ANC visit. IPT-SP users had higher prevalence in both malaria $(25.8 \%)$ and anaemia (33.9\%) compared with non-IPT users $(17.5 \%$ and $24.4 \%$ respectively). However, there was no statistically significant difference between the two cases $(\mathrm{p}=0.165$ and $\mathrm{p}=0.153$ respectively) (Table 3 ). IPT usage was higher among multigravidae than the primigravidae. Participants in the third trimester 
recorded the highest for IPT usage and those in the first trimester recording the least. There was a significant difference between the three groups $(\mathrm{p}<0.0001)$. Table 2 shows the usage of IPT among participants with respect to gravidity and term of pregnancy.

One hundred and forty-six (65.8\%) participants possessed an ITN with 72 (49.3\%) of them sleeping under it the previous night (ITN users). Malaria prevalence was higher $(20.5 \%)$ amongst ITN owners whilst that of the non-owners was $18.4 \%$. Thirty-three $(22.6 \%)$ of ITN owners were anaemic compared to twenty-seven $(35.5 \%)$ of non-owners; and the difference was significant $(\mathrm{p}=0.040)$. Among ITN users, malaria prevalence was $19.4 \%$ and anaemia prevalence $20.8 \%$. For ITN non users, prevalence was $20.0 \%$ and $30.0 \%$ for malaria and anaemia respectively (Table 3).

Table 2: IPT usage among participants

\section{IPT usage n (\%) P-value}

\section{Gravidity}

Primigravida

$22(26.8 \%)$

0.781

Multigravida

$40(28.6 \%)$

\section{Gestational period}

$\begin{array}{lll}\text { 1st Trimester } & 2(2.5 \%) & <0.0001 \\ \text { 2nd Trimester } & 25(23.8 \%) & \\ \text { 3rd Trimester } & 35(94.6 \%) & \end{array}$


Table 3: Maternal characteristics and binary logistic regression analysis on factors associated with malaria and anaemia

\begin{tabular}{|c|c|c|c|c|c|c|c|c|}
\hline \multirow[t]{2}{*}{ Characteristics } & \multicolumn{4}{|c|}{ Malaria } & \multicolumn{4}{|c|}{ Anaemia } \\
\hline & $\mathrm{n}(\%)$ & p-value & Odds ratio $(95 \% \mathrm{CI})$ & p-value & $\mathrm{n}(\%)$ & p-value & Odds ratio $(95 \% \mathrm{CI})$ & p-value \\
\hline Total & $44(19.8)$ & & & & $60(27.0)$ & & & \\
\hline \multicolumn{9}{|l|}{ Age } \\
\hline$<20$ & $8(38.1)$ & 0.027 & $2.821(1.089-7.305)$ & $\mathbf{0 . 0 3 3}$ & $10(47.6)$ & 0.026 & 2.745 (1.101-6.549) & 0.030 \\
\hline$\geq 20$ & $36(17.9)$ & & 1.00 & & $50(24.9)$ & & 1.00 & \\
\hline \multicolumn{9}{|l|}{ Gravidity } \\
\hline Primigravida & $21(25.6)$ & 0.098 & $1.751(0.898-3.414)$ & 0.100 & $26(31.7)$ & 0.229 & $1.447(0.791-2.650)$ & 0.231 \\
\hline Multigravida & $23(16.4)$ & & 1.00 & & $34(24.3)$ & & 1.00 & \\
\hline \multicolumn{9}{|l|}{ Gestational period } \\
\hline $1^{\text {st }}$ Trimester & $8(10.0)$ & 0.022 & $0.346(0.121-0.986)$ & 0.047 & $17(21.3)$ & 0.257 & $0.498(0.210-1.179)$ & 0.113 \\
\hline $2^{\text {nd }}$ Trimester & $27(25.7)$ & & $1.077(0.452-2.569)$ & 0.867 & $20(28.6)$ & & $0.738(0.333-1.638)$ & 0.456 \\
\hline $3^{\text {rd }}$ trimester & $9(24.3)$ & & 1.00 & & $13(35.1)$ & & 1.00 & \\
\hline \multicolumn{9}{|l|}{ Malaria during pregnancy } \\
\hline Yes & $6(33.3)$ & 0.134 & $2.184(0.771-6.189)$ & 0.141 & $3(16.7)$ & 0.302 & $0.516(0.144-1.849)$ & 0.309 \\
\hline No & $38(18.6)$ & & 1.00 & & $57(27.9)$ & & 1.00 & \\
\hline \multicolumn{9}{|l|}{ Setting } \\
\hline Rural (Kuntanase and Agona) & $26(26.3)$ & 0.031 & $2.078(1.062-4.065)$ & 0.033 & $32(32.3)$ & 0.111 & $1.620(0.893-2.940)$ & 0.112 \\
\hline Urban (KNUST and Emena) & $18(14.6)$ & & 1.00 & & $28(22.8)$ & & 1.00 & \\
\hline \multicolumn{9}{|l|}{ IPT } \\
\hline Yes & $16(25.8)$ & 0.165 & 1.00 & & $21(33.9)$ & 0.153 & 1.00 & 0.155 \\
\hline No & $28(17.5)$ & & $1.540(0.814-3.302)$ & 0.166 & $39(24.4)$ & & $0.629(0.333-1.191)$ & \\
\hline \multicolumn{9}{|l|}{ ITN usage } \\
\hline Yes & $14(19.4)$ & 0.923 & 1.00 & & $15(20.8)$ & 0.150 & 1.00 & 0.152 \\
\hline No & & & $1.036(0.510-2.102)$ & 0.923 & & & $1.629(0.836-3.174)$ & \\
\hline \multicolumn{9}{|l|}{ Malaria } \\
\hline Positive & & & & & $24(54.5)$ & $<0.001$ & $4.733(2.357-9.504)$ & $<0.001$ \\
\hline Negative & & & & & $36(20.2)$ & & 1.00 & \\
\hline
\end{tabular}


medRxiv preprint doi: https://doi.org/10.1101/2021.08.12.21261986; this version posted August 13, 2021. The copyright holder for this preprint (which was not certified by peer review) is the author/funder, who has granted medRxiv a license to display the preprint in perpetuity.

It is made available under a CC-BY-NC 4.0 International license .

\subsection{Follow up group}

One hundred participants were recruited for the longitudinal cohort study (follow up). Due to reasons such as migration, change of ANC visit dates and opting out by some participants for personal reasons, fifty-six participants were left for the follow up study. Unfortunately, two of the fifty-six also experienced spontaneous abortion. A total of fifty-four participants were therefore successfully followed up until delivery.

With one hundred and thirty-nine (139) tests performed, the overall prevalence of malaria and anaemia among the participants involved were $18.7 \%$ and $32.4 \%$ respectively. At delivery, twenty-two (40.7\%) out of these, had malaria parasitaemia at least once during the pregnancy period. Twenty-eight (51.9\%) of them were also anaemic at least once during this period. There were twenty-six episodes of malaria among participants who were followed up till delivery. For anaemia, there were forty-five episodes of which twenty-one (46.7\%) were malaria associated. Women who had malaria during pregnancy had increased risk of anaemia $(\mathrm{OR}=10.2095 \% \mathrm{CI}=2.840-36.630, \mathrm{p}<0.001)($ Table 4$)$.

\subsection{Birthweights of babies}

All deliveries were singleton with birthweight ranging from 1.9 to $5.4 \mathrm{~kg}$. The mean birthweight of babies of all participants was $3.185 \mathrm{~kg}( \pm 0.5461)$. Three $(5.6 \%)$ babies out of 54 had low birthweight $(<2.5 \mathrm{~kg})$ and there was one case $(1.9 \%)$ of macrosomia (birthweight $\geq 4.0 \mathrm{~kg}$ ). Table 4 shows maternal characteristics and their effects on birthweight in the follow up group. 
Table 4: Maternal characteristics of participants involved in follow up

\begin{tabular}{|c|c|c|c|c|c|c|c|c|}
\hline & \multirow{2}{*}{$\begin{array}{l}\text { Participants } \\
\mathrm{n}(\%)\end{array}$} & \multicolumn{2}{|c|}{ Malaria } & \multicolumn{2}{|c|}{ Anaemia } & \multirow{2}{*}{$\begin{array}{c}\text { LBW } \\
\mathrm{n}(\%)\end{array}$} & \multicolumn{2}{|c|}{ Mean Birthweight } \\
\hline & & $\mathrm{n}(\%)$ & $\mathrm{p}$-value & $\mathrm{n}(\%)$ & p-value & & $\mathrm{Kg} \pm \mathrm{SD}$ & p-value \\
\hline Total & $54(100)$ & $22(40.7)$ & & $28(51.9)$ & & $3(5.6)$ & $3.185 \pm 0.5461$ & \\
\hline \multicolumn{9}{|l|}{ Age } \\
\hline$<20$ & $4(7.4)$ & $2(50.0)$ & 0.695 & $2(50.0)$ & 0.375 & & $2.950 \pm 0.3697$ & 0.296 \\
\hline$\geq 20$ & $50(92.6)$ & $20(40.0)$ & & $26(52.0)$ & & $3(6.0)$ & $3.204 \pm 0.5562$ & \\
\hline \multicolumn{9}{|l|}{ Gravidity } \\
\hline Primigravida & $15(27.8)$ & $8(53.3)$ & 0.243 & $8(53.3)$ & 0.939 & & $3.133 \pm 0.3697$ & 0.669 \\
\hline Multigravida & $39(72.2)$ & $14(35.9)$ & & $20(51.3)$ & & $3(7.7)$ & $3.205 \pm 0.6035$ & \\
\hline \multicolumn{9}{|l|}{ ANC visits } \\
\hline$<4$ & $2(3.7)$ & $2(100)$ & 0.082 & $1(50.0)$ & 0.957 & & $3.050 \pm 0.7778$ & 0.805 \\
\hline$\geq 4$ & $52(96.3)$ & $20(38.5)$ & & $27(51.9)$ & & $3(5.8)$ & $3.190 \pm 0.4289$ & \\
\hline \multicolumn{9}{|l|}{ IPT dosage } \\
\hline$<3$ & $24(44.4)$ & $11(45.8)$ & 0.496 & $14(58.3)$ & 0.394 & $2(6.7)$ & $3.275 \pm 0.6635$ & 0.364 \\
\hline$\geq 3$ & $30(55.6)$ & $11(36.7)$ & & $14(46.7)$ & & $1(4.2)$ & $3.113 \pm 0.4289$ & \\
\hline \multicolumn{9}{|l|}{ Malaria } \\
\hline Positive & $22(40.7)$ & & & $18(81.8)$ & $<0.001$ & $2(9.1)$ & $3.259 \pm 0.7076$ & 0.415 \\
\hline Negative & $32(59.3)$ & & & $10(31.3)$ & & $1(3.1)$ & $3.134 \pm 0.4053$ & \\
\hline \multicolumn{9}{|l|}{ Anaemia } \\
\hline Anaemic & & & & & & $3(10.7)$ & $3.250 \pm 0.6546$ & $0.9708 *$ \\
\hline Non-anaemic & & & & & & & $3.115 \pm 0.3997$ & \\
\hline Malaria-associated anaemia & & & & & & $2(11.8)$ & $3.282 \pm 0.7683$ & \\
\hline
\end{tabular}


medRxiv preprint doi: https://doi.org/10.1101/2021.08.12.21261986; this version posted August 13, 2021. The copyright holder for this preprint (which was not certified by peer review) is the author/funder, who has granted medRxiv a license to display the preprint in perpetuity.

It is made available under a CC-BY-NC 4.0 International license .

\subsubsection{Effects of malaria and anaemia on birthweight}

The mean of birthweights was higher in participants who were parasitaemic $(3.259 \mathrm{~kg}$ $\pm 0.7076)$ and anaemic $(3.250 \mathrm{~kg} \pm 0.6546)$ during the pregnancy period (Table 4). However, there was no significant difference in mean birthweights between parasitaemic and nonparasitaemic women. The same was observed for anaemic and non-anaemic women. The mean birthweight of babies born to mothers who had malaria-associated anaemia was 3.282 $\mathrm{kg} \pm 0.7683$ and there was no significant difference between them and that of babies born to non-malaria-associated anaemic mothers (Table 4).

\subsubsection{Effects of frequency of malaria and anaemia on birthweight}

Out of the total (22) who had malaria during the pregnancy period, 3 had the infection more than once. In comparing the means of birthweight, participants who had malaria once during the period had a higher mean birthweight $(3.217 \mathrm{~kg} \pm 0.4878)$ than those who had the infection more than once $(2.800 \mathrm{~kg} \pm 0.7810)$. The same trend was seen for anaemia where participants who were anaemic once $(14(50 \%))$ in the pregnancy period had a higher mean birthweight $(3.179 \mathrm{~kg} \pm 0.4191)$ than those who were anaemic more than once $(3.162$ \pm 0.6117 ) (Table 5). Nonetheless, there were no significant difference in mean birthweights between mothers in both malaria and anaemia. Participants who had malaria-associated anaemia once during the pregnancy period also had a higher mean birthweight $(3.231 \mathrm{~kg}$ $\pm 5006)$ compared to those who had it twice or more $(2.800 \mathrm{~kg} \pm 7810)$. This difference was also not statistically significant.

\subsubsection{Effects of timing of malaria and anaemia on birthweight}

The timing of the infection and anaemia in terms of trimester in which they occurred were also taken. For malaria, $13(59.1 \%)$ of infection occurred in the second trimester compared to $5(22.7 \%)$ in the third trimester. Three participants had malaria in both the second and third 
trimesters accounting for $13.6 \%$ of total infections. Amongst participants who had anaemia during the pregnancy period, the highest number (42.9\%) of them were anaemic in both the second and third trimesters compared to $17.9 \%$ and $32.1 \%$ in the second and third trimesters respectively (Table 5).

The participants who had the infection in the second trimester alone had the highest mean birthweight of babies $(3.285 \mathrm{~kg} \pm 0.5145)$ followed by third trimester alone $(3.040 \mathrm{~kg}$ $\pm 0.4037)$ and both second and third trimesters $(2.800 \mathrm{~kg} \pm 0.7810)$. The same trend was seen for anaemia. However, these were not statistically significant (Table 5).

Table 5: Effects of frequency and timing of malaria and anaemia on birthweight of babies

\begin{tabular}{llll}
\hline & $\begin{array}{l}\text { Participants } \\
\mathbf{N}(\boldsymbol{\%})\end{array}$ & $\begin{array}{l}\text { Mean birthweight } \\
( \pm \mathbf{S D})(\mathbf{k g})\end{array}$ & P-value \\
\hline Total & $54(100)$ & $3.185 \pm 0.5461$ & \\
Malaria & $22(40.7)$ & & \\
Frequency & & & \\
1 & $18(81.8)$ & $3.217 \pm 0.4878$ & 0.2714 \\
$>1$ & $3(13.6)$ & $2.800 \pm 0.7810$ & \\
& & & \\
Timing & & $3.285 \pm 0.5145$ & \\
$2^{\text {nd }}$ trimester & $13(59.1)$ & $3.040 \pm 0.4037$ & \\
$3^{\text {rd }}$ trimester & $5(22.7)$ & $2.800 \pm 0.7810$ & \\
$2^{\text {nd }}$ and $3^{\text {rd }}$ trimester & $3(13.6)$ & & \\
& & & \\
Anaemia & $28(51.9)$ & $3.179 \pm 0.4191$ & \\
Frequency & & $3.162 \pm 0.6117$ & \\
1 & $14(50.0)$ & & \\
$>1$ & $13(46.4)$ & & \\
& & & \\
Timing & & & \\
$2^{\text {nd }}$ trimester & $5(17.9)$ & & \\
$3^{\text {rd }}$ trimester & $9(32.1)$ & & \\
$2^{\text {nd }}$ and $3^{\text {rd }}$ trimester & $12(42.9)$ & & \\
\hline
\end{tabular}




\subsection{Discussion}

Close to half of the participants involved in the present study did not take the recommended dose of SP during the pregnancy period, especially those from the rural areas. This could be due to the lifestyle of the pregnant women attending ANC as and when they feel ill instead of the routine planned dates of visits. This in turn exposes the pregnant women and their unborn babies to the adversities of malaria.

Being pregnant alone is a major factor that compromises the immune response of women, increasing their vulnerability to majority of infectious diseases (Sappenfield et al., 2013; Tay et al., 2017). Therefore, during pregnancy, the infection poses a high risk to the mother especially the primigravidae (Valente et al., 2011). Risks associated with malaria during pregnancy include foetal death, premature delivery, intra-uterine growth retardation, low birthweight, maternal anaemia and mortality (Wini et al., 2013).

The overall prevalence of malaria at enrolment was 19.8\%. Ofori et al., (2009) and Enato et al., (2009) recorded similar prevalence amongst pregnant women in the Greater Accra region and Nigeria respectively. This is higher than the prevalence of the infection that was recorded in several studies in Ghana among comparatively larger sample sizes (Ampofo et al., 2018; Helegbe et al., 2018; Osarfo et al., 2017). Other studies in Angola and Malawi have respectively reported $8.6 \%$ (Valente et al., 2011) and 11.9\% (Rogawski et al., 2012) of the infection among pregnant women. The higher prevalence recorded in the present study could be due to participants who came from the rural areas as hospitals that included more of such participants had increased odds of infection. However, there are other studies that have reported higher prevalence than what has been reported in this study (Agan et al., 2010a; Akinboro et al., 2010; Anchang-Kimbi et al., 2015). This is because these studies were 
conducted in stable transmission areas, majority of pregnant women coming for the first time and also registering late at the ANC.

Van-Spronsen et al., (2012) found a prevalence of anaemia (27\%) similar to that of the present study. A relatively higher pregnancy-associated anaemia has been reported in earlier studies in the country, in the Greater Accra region (Tay et al., 2017) and in Nigeria (Agan et al., 2010b) with a $66.4 \%$ and $59.6 \%$ prevalence respectively. Malaria-associated anaemia was $54.5 \%$ among participants in the present study. Also, malaria-positive women were more likely to have anaemia and this association was statistically significant with a p-value $<0.001$. However, not all pregnant women who were anaemic were malaria positive. This could be as a result of other factors that cause anaemia during pregnancy such as HIV, helminth infections, folate and nutritional deficiencies (Glover-Amengor et al., 2005).

Agona and Kuntanase Government hospitals are in peri-urban settings and have most of their attendants coming from neighbouring rural communities. Malaria transmission is affected by location and rural populations are at greater risk of the infection (Rogerson et al., 2018). This is due to the availability of suitable environments for vector breeding from poor sanitation and the absence of appropriate control measures (Kimbi et al., 2013; Molina Gómez et al., 2017). Thus, the higher infection prevalence recorded in these hospitals than in KNUST hospital and Aniniwah Medical Centre. However, it must be stated that even though KNUST hospital and Aniniwah Medical Centre are both located in an urban area, approximately 6.4 $\mathrm{km}$ apart, the prevalence of malaria and anaemia recorded in the latter is far greater than the former. This could be attributed to difference in several factors including lifestyle of pregnant women who reported to both hospitals which may increase or decrease their vulnerability to both malaria and anaemia. Moreover, majority of the pregnant women reporting to both hospitals were attending ANC for the first time. Future studies can look into factors that may be responsible for these differences. 
In this study, it was observed that younger pregnant women were more prone to both malaria and anaemia than their older counterparts with higher prevalence. There was a significant correlation between both malaria $(\mathrm{p}=0.027)$ and anaemia $(\mathrm{p}=0.026)$ in younger and older pregnant women. Also, primigravid women were found to be more parasitaemic compared to their multigravida counterparts. A study in Nigeria also reported similar prevalence of malaria (24.3\%) among primigravid women (Enato et al., 2009). However, the difference in the present study was not significant. This is in disagreement with findings of a study which found a significantly higher parasitaemia in primigravid women (Agan et al., 2010a). Most of the younger pregnant women $(95.2 \%)$ in this study were primigravidae. Being young and primigravid have been reported to be a risk factor for malaria infection and its associated anaemia in several studies (Anchang-Kimbi et al., 2015; McClure et al., 2014; Orish et al., 2012; Tay et al., 2013). Compared with their multigravida counterparts, primigravid women are also known to be vulnerable to infections especially malaria (Rogerson et al., 2018). Due to multiple pregnancies, multigravida women tend to be exposed to the infection for longer periods with occasional infection of their placentas, therefore develop partial immunity in successive pregnancies (Moya-Alvarez et al., 2014; Wassmer and Grau, 2016). Furthermore, experience and knowledge of malaria and its prevention during pregnancy by multigravida woman could also be an advantage. Although the level of immunity is a determinant of the susceptibility to, and severity of malaria, it is also affected by the infection intensity and transmission stability (Sappenfield et al., 2013).

With gestational age, women in the second trimester had the highest prevalence of the infection. Similar observation was made by Afrifa et al., (2017) amongst malaria positive pregnant women in Koforidua, in the Eastern region of Ghana. It is recommended by WHO to administer IPT-SP in the $16^{\text {th }}$ week of pregnancy, which is in the second trimester (Wini et al., 2013). Therefore, under normal circumstances, this is the stage at which treatment of 
malaria infection would take place thereby reducing the infection prevalence. Some studies also found that pregnant women have increased chances of getting infected in the first half of pregnancy which is within the first and second trimesters (Huynh et al., 2011; Valea et al., 2012).

The prevalence of anaemia was highest in participants in their third trimester which is similar to findings by Tay et al., (2013). In the third trimester of pregnancy, anaemia has been reported to occur in about one third of women with major causes being iron and folate deficiencies (Friel, 2020). On the contrary, other studies reported reduced prevalence of anaemia in the third trimester (Anlaakuu and Anto, 2017; Nega et al., 2015). Prevalence of anaemia has been reported to be different in different countries and also different within regions of a country (Koyuncu et al., 2017). Difference in national policies and socioeconomic status may be accountable for this observation.

The World Health Organization recommends intermittent preventive treatment with sulphadoxine-pyrimethamine (IPT-SP) together with the use of insecticide-treated nets as a means of protection of women from malaria during pregnancy (WHO, 2014).

The national coverage target of IPT-SP and ITN is 80\% (Orish et al., 2015; Stephen et al., 2016). In the present study, IPT-SP coverage was $27.9 \%$ at enrolment and this included participants who were coming to ANC for the first time as well as participants who were in the early stage of pregnancy (below 16 weeks). Comparing IPT-SP users and non-users, IPTSP users had higher prevalence of both malaria and anaemia. This could be as a result of exposure of IPT-SP users to repeated infectious mosquito bites thereby resulting in infection and also other factors which may lead to anaemia such as helminth infection, iron and folate deficiencies. Nonetheless, this difference was not statistically significant. Orish et al., (2015) also found IPT-SP users to have higher prevalence of anaemia compared to non-users. IPT- 
medRxiv preprint doi: https://doi.org/10.1101/2021.08.12.21261986; this version posted August 13, 2021. The copyright holder for this preprint

$\mathrm{SP}$ is known to be effective in reducing maternal parasitaemia and its associated complications such as anaemia (Esu et al., 2018). Other studies found that IPT users had less parasitaemia and anaemia compared to IPT non-users (Tutu et al., 2010; Wilson et al., 2011).

As part of strategies to eliminate malaria, protective measures such as protection from mosquito bites is an integral part. As such, in Ghana, as part of ANC registration, insecticide treated nets are given in efforts to protect the pregnant woman and her unborn child. In the present study, at enrolment, ITN ownership was $65.8 \%$ but usage was $49.3 \%$ the night before their recruitment into the study. Osarfo et al., (2017) also reported 60\% ITN ownership and $40 \%$ ITN usage. Reasons for not owning or using the nets included hot conditions inside the net and the use of other vector control measures. Similar complaints were made by pregnant women in a study in the Brong Ahafo region of Ghana (Manu et al., 2017).

The prevalence of malaria amongst ITN owners was $20.5 \%$ and in those who slept under it the night before, $19.4 \%$. Amongst non-owners, the prevalence (18.4\%) was lower. These differences, however, were not statistically significant. Thus, using ITN did not provide extra protection to the pregnant women. This could be attributed to infectious vector bites prior to the use of the net or even after use, as a result of different lifestyle behaviours or in cases where there are no other control measures used. Similar observations were made by Browne et al., (2001).

In the longitudinal study, there was a follow-up on fifty-four pregnant women up to delivery of their babies. The mean number of ANC visits was $8.26 \pm 2.665$ which was higher than what was observed in other studies in the country (Asundep et al., 2014; Völker et al., 2017). Antenatal Care (ANC) is an integral tool in the improvement of maternal and neonatal health through the early detection and management of complications during pregnancy (Sumankuuro et al., 2017). In the present study, 52 (96.3\%) visited ANC four times or more 
which is the least recommendation for uncomplicated pregnancy (Asundep et al., 2014). This was higher than the findings of a study which reported $74.6 \%$ of participants attending ANC four or more times (Addai-Mensah et al., 2018). Malaria was more prevalent among this group of pregnant women and this could be as a result of the reduced number of SP taken as none was able to take the recommended dosage. However, there was no significant difference between the two groups. Increasing ANC visits have been reported to provide the opportunity for increased uptake of SP thereby increasing protection (Nkoka et al., 2018).

IPT-SP uptake among participants in the follow up study was $100 \%$ with only $55.6 \%$ (30) out of this taking the recommended 3 or more dosages. This, however, did not have any significant impact on the prevalence of malaria and anaemia in both groups. Increase in SP taken during pregnancy is reported to minimize malaria and its associated complications such as anaemia and low birthweight (Valea et al., 2012). A single dose of SP has been reported to provide protection from malaria and its consequences. This is supported by findings from the present study and that of Tutu et al., (2011b).

In Sub-Saharan Africa, malaria and anaemia are major contributors to poor birth outcomes such as spontaneous abortion, preterm delivery and low birthweight (Tutu et al., 2011a). In the present study, the poor birth outcomes recorded were spontaneous abortion and low birthweight. The overall mean birthweight for all babies in the present study was $3.185 \mathrm{~kg}$ $( \pm 0.5461)$. This is higher than that reported from Benin $(2.9982 \mathrm{~kg} \pm 0.474)$ (Huynh et al., 2011). Low birthweight was seen in three (5.6\%) of the babies, a mean birthweight of 2.067 $\mathrm{kg}( \pm 0.1528)$. Previous studies have reported higher percentages of low birthweight babies among maternal cohorts in Ghana (Laar et al., 2013) and in Benin (Huynh et al., 2011). However, another study conducted in the Greater Accra region of Ghana recorded a lower LBW prevalence of 3.3\% (Stephens et al., 2014). 
In the present study, it was observed that neither time of infection nor its frequency had a significant impact on the mean birth weight of babies. However, Huynh et al., (2011) reported that mothers who had an infection in the second trimester had higher mean birthweight babies compared to those who had infection in the third trimester. Similar observation was also made regarding whether or not a mother took the recommended dose of $\mathrm{SP}$ as it had no impact on the mean birthweight of babies. This is in disagreement with a study in Cameroon which found a higher mean birthweight of babies born to pregnant women who took the full course of IPT (3 doses) (Yoah et al., 2018). Increasing dosage of IPT-SP has been found to be associated with higher mean birthweight and reduces the incidence of LBW (WHO, 2014). However, according to Tutu et al., (2011b), taking a single dose of SP can improve the birthweight of babies.

Overall, in the present study, malaria and anaemia had no significant impact on birthweight of babies. Similar observation was made by another study which found no association between anaemia and low birthweight (Port et al., 2012). This could be attributed to the lower number of low birthweights recorded. Furthermore, the lower number of low birthweight babies and the less impact of both malaria and anaemia could be attributed to the $100 \%$ uptake of SP and ITN usage among the follow-up pregnant women during their pregnancy period. These have been reported to provide extra protection to women during pregnancy. Also, a higher percentage of women visited ANC for the recommended number for uncomplicated pregnancy.

Nonetheless, several studies have found malaria and anaemia to be significantly associated with low birthweight (Guyatt and Snow, 2004; Nair et al., 2018; Wini et al., 2013). 


\subsection{Conclusion}

The findings from this study suggest that malaria and anaemia are still prevalent among pregnant women. Malaria was significantly associated with anaemia during pregnancy. Pregnant women of age lesser than 20 years as well as rural dwellers are at higher risk of malaria. Low birth weight was lower among babies born to the pregnant women. Malaria and anaemia did not have a significant impact on the birthweight of the babies. ITN and IPTSP usage were also high but had no significant impact on malaria, anaemia and birthweight of babies born to the pregnant women. Education of women of child bearing age on the possible risk of malaria and anaemia during pregnancy on the pregnant woman and her foetus, should be intensified. Furthermore, education on malaria prevention and use of preventive measures especially in rural areas should be encouraged.

\section{Authors' contributions}

Dawood Ackom Abbas: Conceptualization, Methodology, Resources, Investigation, Formal analysis, writing - original draft; Kingsley Badu and Bernard Walter Lartekwei Lawson: Conceptualization, Methodology, Resources, Validation, Supervision, Writing - Review \& Editing; Abdul-Hakim Mutala, Samuel Kekeli Agordzo and Christian Kwasi Owusu: Investigation, Formal analysis, Writing - Review \& Editing

\section{Conflict of interests}

The authors declare that they have no conflict of interest.

\section{Acknowledgements}


medRxiv preprint doi: https://doi.org/10.1101/2021.08.12.21261986; this version posted August 13, 2021. The copyright holder for this preprint (which was not certified by peer review) is the author/funder, who has granted medRxiv a license to display the preprint in perpetuity.

It is made available under a CC-BY-NC 4.0 International license.

The authors would like to thank all pregnant women who participated in the study. Special gratitude to midwives and laboratory technicians in the respective study areas. 
medRxiv preprint doi: https://doi.org/10.1101/2021.08.12.21261986; this version posted August 13, 2021. The copyright holder for this preprint (which was not certified by peer review) is the author/funder, who has granted medRxiv a license to display the preprint in perpetuity.

It is made available under a CC-BY-NC 4.0 International license .

\section{References}

Addai-Mensah, O., Annani-Akollor, M.E., Fondjo, L.A., Sarbeng, K., Anto, E.O., Owiredu, E.-W., Arthur, S.N., 2018. Regular Antenatal Attendance and Education Influence the Uptake of Intermittent Preventive Treatment of Malaria in Pregnancy: A CrossSectional Study at the University Hospital, Kumasi, Ghana. J. Trop. Med. 1-8. https://doi.org/10.1155/2018/5019215

Afrifa, J., Essien-Baidoo, S., Baffour Gyau, A., Ephraim, R.K.D., 2017. Evaluation of Renal Function in Pregnant Women with Malaria: A Case-Control Study in a Mesoendemic Area. Obstet. Gynecol. Int. https://doi.org/10.1155/2017/6030943

Agan, T., Ekabua, J., Iklaki, C., Oyo-Ita, A., Ibanga, I., 2010a. Prevalence of asymptomatic malaria parasitaemia. Asian Pac. J. Trop. Med. 51-54. https://doi.org/10.1016/S1995$7645(10) 60032-6$

Agan, T., Ekabua, J.E., Udoh, A.E., Ekanem, E.I., Efiok, E.E., Mgbekem, M.A., 2010 b. Prevalence of anemia in women with asymptomatic malaria parasitemia at first antenatal care visit at the University of Calabar Teaching Hospital, Calabar, Nigeria. Int. J.

Womens. Health 2, 229-233. https://doi.org/10.2147/IJWH.S11887

Akinboro, R.A., Ojurongbe, O., Akindele, A.A., Adefioye, O.A., Bolaji, O.S., Olaniran, O., Adeyeba, O.A., 2010. Plasmodium falciparium Parasitemia in Pregnancy in Relation to maternal anaemia. African J. Clin. Exp. Microbiol. 11, 164-169.

Ampofo, G.D., Tagbor, H., Bates, I., 2018. Effectiveness of pregnant women's active participation in their antenatal care for the control of malaria and anaemia in pregnancy in Ghana: a cluster randomized controlled trial. Malar. J. 17, 238.

https://doi.org/10.1186/s12936-018-2387-1 
Anchang-Kimbi, J.K., Nkweti, V.N., Ntonifor, H.N., Apinjoh, T.O., Tata, R.B., Chi, H.F., Achidi, E.A., 2015. Plasmodium falciparum parasitaemia and malaria among pregnant women at first clinic visit in the mount Cameroon Area. BMC Infect. Dis. 15, 1-10. https://doi.org/10.1186/s12879-015-1211-6

Anlaakuu, P., Anto, F., 2017. Anaemia in pregnancy and associated factors: a cross sectional study of antenatal attendants at the Sunyani Municipal Hospital, Ghana. BMC Res. Notes 10. https://doi.org/10.1186/s13104-017-2742-2

Asundep, N.N., Jolly, P.E., Carson, A., Turpin, C.A., Zhang, K., Tameru, B., 2014. Antenatal Care Attendance, a Surrogate for Pregnancy Outcome $\square$ ? The Case of Kumasi, Ghana. Matern. Child Health J. 18, 1085-1094. https://doi.org/10.1007/s10995-013-1338-2

Browne, E.N.L., Maude, G.H., Binka, F.N., 2001. The impact of insecticide-treated bednets on malaria and anaemia in pregnancy in Kassena-Nankana district, Ghana: A randomized controlled trial. Trop. Med. Int. Heal. 6, 667-676. https://doi.org/10.1046/j.1365-3156.2001.00759.x

Enato, E.F.O., Mens, P.F., Okhamafe, A.O., Okpere, E.E., Pogoson, E., Schallig, H.D.F.H., 2009. Plasmodium falciparum malaria in pregnancy: Prevalence of peripheral parasitaemia, anaemia and malaria care-seeking behaviour among pregnant women attending two antenatal clinics in Edo State, Nigeria. J. Obstet. Gynaecol. (Lahore). 29, 301-306. https://doi.org/10.1080/01443610902883320

Esu, E., Berens-Riha, N., Pritsch, M., Nwachuku, N., Loescher, T., Meremikwu, M., 2018. Intermittent screening and treatment with artemether-lumefantrine versus intermittent preventive treatment with sulfadoxine-pyrimethamine for malaria in pregnancy: A facility-based, open-label, non-inferiority trial in Nigeria. Malar. J. 17, 1-12. https://doi.org/10.1186/s12936-018-2394-2 
Friel, L.A., 2020. Anemia in Pregnancy [WWW Document]. URL

https://www.msdmanuals.com/professional/gynecology-and-obstetrics/pregnancycomplicated-by-disease/anemia-in-pregnancy (accessed 11.22.20).

Ghana Health Service, 2021. Newborn Care Programme [WWW Document]. URL https://ghanahealthservice.org/newborn/ (accessed 1.21.21).

Glover-Amengor, M., Owusu, W.B., Akanmori, B.D., 2005. Determinants of anaemia in pregnancy in Sekyere West district, Ghana. Ghana Med. J. 39, 102-107.

Guyatt, H.L., Snow, R.W., 2004. Impact of malaria during pregnancy on low birth weight in sub-Saharan Africa. Clin. Microbiol. Rev. 17, 760-9. https://doi.org/10.1128/CMR.17.4.760

Helegbe, G.K., Aryee, P.A., Mohammed, B.S., Wemakor, A., Kolbila, D., Abubakari, A., Askanda, S., Alhassan, R., Barnie, C., Donkoh, A.A., Ofosu, E., 2018. Seroprevalence of Malaria and Hepatitis B Coinfection among Pregnant Women in Tamale Metropolis of Ghana $\square$ : A Cross-Sectional Study. Can. J. Infect. Dis. Med. Microbiol. 2018.

Huynh, B.-T., Fievet, N., Gbaguidi, G., Dechavanne, S., Borgella, S., Guézo-Mévo, B., Massougbodji, A., Tuikue Ndam, N., Deloron, P., Cot, M., 2011. Influence of the timing of malaria infection during pregnancy on birth weight and on maternal anemia in Benin. Am. J. Trop. Med. Hyg. 85, 214-220. https://doi.org/10.4269/ajtmh.2011.11-0103

Ibrahim, H., Maya, E.T., Issah, K., Apanga, P.A., Bachan, E.G., Noora, C.L., 2017. Factors influencing uptake of intermittent preventive treatment of malaria in pregnancy using sulphadoxine pyrimethamine in Sunyani Municipality, Ghana. Pan Afr. Med. J. 8688, 112. https://doi.org/10.11604/pamj.2017.28.122.12611

Iqbal, S.A., Botchway, F., Badu, K., Wilson, N.O., Dei-Adomakoh, Y., Dickinson-Copeland, 
C.M., Chinbuah, H., Adjei, A.A., Wilson, M., Stiles, J.K., Driss, A., 2016.

Hematological differences among malaria patients in rural and Urban Ghana. J. Trop.

Pediatr. 62, 477-486. https://doi.org/10.1093/tropej/fmw038

Kimbi, H.K., Nana, Y., Sumbele, I.N., Anchang-Kimbi, J.K., Lum, E., Tonga, C., Nweboh,

M., Lehman, L.G., 2013. Environmental Factors and Preventive Methods against

Malaria Parasite Prevalence in Rural Bomaka and Urban Molyko, Southwest Cameroon.

J. Bacteriol. Parasitol. 04, 1-5. https://doi.org/10.4172/2155-9597.1000162

Koyuncu, K., Turgay, B., Şükür, Y.E., Yıldırım, B., Ateş, C., Söylemez, F., 2017. Third trimester anemia extends the length of hospital stay after delivery. Turkish J. Obstet. Gynecol. 14, 166-169. https://doi.org/10.4274/tjod.87864

Laar, A.K., Grant, F.E., Addo, Y., Soyiri, I., Nkansah, B., Abugri, J., Laar, A.S., 2013. Predictors of fetal anemia and cord blood malaria parasitemia among newborns of HIVpositive mothers. BMC Res. Notes 6, 1. https://doi.org/10.1186/1756-0500-6-350

Manu, G., Boamah-kaali, E.A., Febir, L.G., Ayipah, E., Owusu-Agyei, S., Asante, K.P., 2017. Low Utilization of Insecticide-Treated Bed Net among Pregnant Women in the Middle Belt of Ghana. Malar. Res. Treat. 2017. https://doi.org/10.1155/2017/7481210

McClure, E.M., Meshnick, S.R., Lazebnik, N., Mungai, P., King, C.L., Hudgens, M., Goldenberg, R.L., Siega-riz, A., Dent, A.E., 2014. A cohort study of Plasmodium falciparum malaria in pregnancy and associations with uteroplacental blood fl ow and fetal anthropometrics in Kenya. Int. J. Gynecol. Obstet. 126, 78-82.

https://doi.org/10.1016/j.ijgo.2014.01.016

Molina Gómez, K., Caicedo, M.A., Gaitán, A., Herrera-Varela, M., Arce, M.I., Vallejo, A.F., Padilla, J., Chaparro, P., Pacheco, M.A., Escalante, A.A., Arevalo-Herrera, M., Herrera, S., 2017. Characterizing the malaria rural-to-urban transmission interface: The 
importance of reactive case detection. PLoS Negl. Trop. Dis. 11.

https://doi.org/10.1371/journal.pntd.0005780

Moya-Alvarez, V., Abellana, R., Cot, M., 2014. Pregnancy-associated malaria and malaria in infants $\square$ : an old problem with present consequences. Malar. J. 13.

Nair, M., Gireesh, S., Yakoob, R., Cheriyan, N.C., 2018. Effect of maternal anaemia on birth weight of term babies. Int. J. Contemp. Pediatr. 5, 1019-1022. https://doi.org/10.18203/2349-3291.ijcp20181533

Nega, D., Dana, D., Tefera, T., Eshetu, T., 2015. Anemia associated with asymptomatic malaria among pregnant women in the rural surroundings of Arba Minch Town, South Ethiopia. BMC Res. Notes 8. https://doi.org/10.1186/s13104-015-1081-4

Nkoka, O., Chuang, T.W., Chen, Y.H., 2018. Association between timing and number of antenatal care visits on uptake of intermittent preventive treatment for malaria during pregnancy among Malawian women. Malar. J. 17. https://doi.org/10.1186/s12936-0182360-z

Ofori, M.F., Ansah, E., Agyepong, I., Hviid, L., Akanmori, B.D., 2009. Pregnancy-associated malaria in a rural community of Ghana. Ghana Med. J. 43, 13-18.

Orish, V.N., Onyeabor, O.S., Boampong, J.N., Afoakwah, R., Nwaefuna, E., Acquah, S., Sanyaolu, A.O., Iriemenam, N.C., 2015. Prevalence of intermittent preventive treatment with sulphadoxine-pyrimethamine (IPTp-SP) use during pregnancy and other associated factors in Sekondi-Takoradi, Ghana. Afr. Health Sci. 15, 1087-1096.

Orish, V.N., Onyeabor, O.S., Boampong, J.N., Aforakwah, R., Nwaefuna, E., Iriemenam, N.C., 2012. Adolescent pregnancy and the risk of Plasmodium falciparum malaria and anaemia - A pilot study from Sekondi-Takoradi metropolis, Ghana. Acta Trop. 123, 
medRxiv preprint doi: https://doi.org/10.1101/2021.08.12.21261986; this version posted August 13, 2021. The copyright holder for this preprint (which was not certified by peer review) is the author/funder, who has granted medRxiv a license to display the preprint in perpetuity.

It is made available under a CC-BY-NC 4.0 International license .

244-248. https://doi.org/10.1016/j.actatropica.2012.05.014

Osarfo, J., Tagbor, H., Cairns, M., Alifrangis, M., Magnussen, P., 2017. Dihydroartemisininpiperaquine versus artesunate-amodiaquine for treatment of malaria infection in pregnancy in Ghana: an open-label, randomized, non-inferiority trial. ARPN J. Eng. Appl. Sci. 12, 3218-3221. https://doi.org/10.1111/ijlh.12426

Owusu-Agyei, S., Awini, E., Anto, F., Mensah-Afful, T., Adjuik, M., Hodgson, A., Afari, E., Binka, F., 2007. Assessing malaria control in the Kassena-Nankana district of northern Ghana through repeated surveys using the RBM tools. Malar. J. 6. https://doi.org/10.1186/1475-2875-6-103

Owusu Adjah, E.S., Panayiotou, A.G., 2014. Impact of malaria related messages on insecticide-treated net (ITN) use for malaria prevention in Ghana. Malar. J. 13. https://doi.org/10.1186/1475-2875-13-123

Port, L., Watier, L., Cottrell, G., Choudat, I., Rachas, A., Bouscaillou, J., Massougbodji, A., 2012. Anaemia during pregnancy $\square$ : impact on birth outcome and infant haemoglobin level during the first 18 months of life. Trop. Med. Int. Heal. 17, 283-291. https://doi.org/10.1111/j.1365-3156.2011.02932.x

Rogawski, E.T., Chaluluka, E., Molyneux, M.E., Feng, G., Rogerson, S.J., Meshnick, S.R., 2012. The effects of malaria and intermittent preventive treatment during pregnancy on fetal anemia in Malawi. Clin. Infect. Dis. 55, 1096-1102. https://doi.org/10.1002/14651858.CD002283.pub4

Rogerson, S.J., Desai, M., Mayor, A., Sicuri, E., Taylor, S.M., Eijk, A.M. Van, 2018. Burden, pathology, and costs of malaria in pregnancy: new developments for an old problem. Lancet Infect. Dis. 18, e107-e118. https://doi.org/10.1016/S1473-3099(18)30066-5 
medRxiv preprint doi: https://doi.org/10.1101/2021.08.12.21261986; this version posted August 13, 2021. The copyright holder for this preprint (which was not certified by peer review) is the author/funder, who has granted medRxiv a license to display the preprint in perpetuity.

It is made available under a CC-BY-NC 4.0 International license .

Saaka, M., Oosthuizen, J., Beatty, S.E., 2009. Effect Of Joint Iron And Zinc Supplementation On Malarial Infection And Anaemia. East Africa J. Public Heal. 6, 55-62. https://doi.org/10.4314/eajph.v6i1.45748

Sappenfield, E., Jamieson, D.J., Kourtis, A.P., 2013. Pregnancy and susceptibility to infectious diseases. Infect. Dis. Obstet. Gynecol. 2013. https://doi.org/10.1155/2013/752852

Stephen, A.A., Wurapa, F., Afari, E.A., Sackey, S.O., Malm, K.L., Nyarko, M., 2016. Factors influencing utilization of intermittent preventive treatment for pregnancy in the Gushegu. Pan Afr. Med. J. 25. https://doi.org/10.11604/pamj.supp.2016.25.1.6169

Stephens, J.K., Ofori, M.F., Quakyi, I.A. kyinbah, Wilson, M.L. ee, Akanmori, B.D. icky, 2014. Prevalence of peripheral blood parasitaemia, anaemia and low birthweight among pregnant women in a suburban area in coastal Ghana. Pan Afr. Med. J. 17. https://doi.org/10.11694/pamj.supp.2014.17.1.3541

Sumankuuro, J., Crockett, J., Wang, S., 2017. The use of antenatal care in two rural districts of Upper West Region, Ghana. PLoS One 12, e0185537. https://doi.org/10.1371/journal.pone.0185537

Tay, S.C.K., Agboli, E., Abruquah, H.H., Walana, W., 2013. Malaria and Anaemia in Pregnant and Non-Pregnant Women of Child-Bearing Age at the University Hospital ,. Open J. Med. Microbiol. 3, 193-200. https://doi.org/10.4236/ojmm.2013.33029

Tay, S.C.K., Nani, E.A., Walana, W., 2017. Parasitic infections and maternal anaemia among expectant mothers in the Dangme East District of Ghana. BMC Res. Notes 10. https://doi.org/10.1186/s13104-016-2327-5

Tutu, E.O., Lawson, B., Browne, E., 2011a. The effectiveness and perception of the use of 
sulphadoxine-pyrimethamine in intermittent preventive treatment of malaria in pregnancy programme in Offinso district of ashanti region, Ghana. Malar. J. 10. https://doi.org/10.1186/1475-2875-10-385

Tutu, E.O., Lawson, B., Browne, E., 2011b. Effect of sulphadoxine-pyrimethamine on neonatal birth weight and perceptions on its impact on malaria in pregnancy in an intermittent preventive treatment programme setting in Offinso District, Ghana. Int. Health 3, 206-212. https://doi.org/10.1016/j.inhe.2011.04.002

Tutu, E.O., Otupiri, E., Larbi, J., Brown, C., Browne, E., Lawson, B., 2010. The effect of intermittent preventive treatment using sulphadoxine pyrimethamine in control of malaria in pregnancy: A cross-sectional study in the Offinso district of Ghana. J. Public Heal. Epidemiol. 2, 53-59.

Valea, I., Tinto, H., Drabo, M.K., Huybregts, L., Sorgho, H., Ouedraogo, J.-B., Guiguemde, R.T., van Geertruyden, J., Kolsteren, P., D’Alessandro, U., 2012. An analysis of timing and frequency of malaria infection during pregnancy in relation to the risk of low birth weight, anaemia and perinatal mortality in Burkina Faso. Malar. J. 11, 71. https://doi.org/10.1186/1475-2875-11-71

Valente, B., Campos, P.A., do Rosario, V.E., Varandas, L., Silveira, H., 2011. Prevalence and risk factors of Plasmodium falciparum infections in pregnant women of Luanda, Angola. Trop. Med. Int. Heal. 16, 1206-1214. https://doi.org/10.1111/j.13653156.2011.02830.x

Van-Spronsen, J.H.M., Schneider, T.A.J., Atasige, S., 2012. Placental malaria and the relationship to pregnancy outcome at Gushegu District Hospital, Northern Ghana. Trop. Doct. $42,80-84$.

Völker, F., Cooper, P., Bader, O., Uy, A., Zimmermann, O., Lugert, R., Groß, U., 2017. 
medRxiv preprint doi: https://doi.org/10.1101/2021.08.12.21261986; this version posted August 13, 2021. The copyright holder for this preprint (which was not certified by peer review) is the author/funder, who has granted medRxiv a license to display the preprint in perpetuity.

It is made available under a CC-BY-NC 4.0 International license .

Prevalence of pregnancy-relevant infections in a rural setting of Ghana. BMC Pregnancy Childbirth 17. https://doi.org/10.1186/s12884-017-1351-3

Wassmer, S.C., Grau, R.E.G., 2016. Severe malaria $\square$ : what's new on the pathogenesis front?

Int. J. Parasitol. 47, 145-152. https://doi.org/10.1016/j.ijpara.2016.08.002

WHO, 2016. International statistical classification of diseases and related health problems, 10th revision (ICD-10), Fifth version, 5th ed. Geneva.

WHO, 2014. WHO policy brief for the Implementation of Intermittent Preventive Treatment of Malaria in Pregnancy Using Sulfadoxine-Pyrimethamine (IPTp-SP). WHO Press 113. https://doi.org/WHO/HTM/GMP/2014.4

WHO, 2010. Basic Malaria Microscopy, 2nd ed.

WHO, 2001. Iron deficiency anaemia: assessment, prevention, and control, a guide for programme managers. World Health Organization, Geneva.

WHO, UNICEF, UNFPA, World Bank Group, United Nations Population Division, 2019. Maternal mortality in 2000-2017 Internationally comparable MMR estimates by the Maternal Mortality Estimation Inter-Agency Group ( MMEIG ) 1-8.

Wilson, N.O., Ceesay, F.K., Obed, S.A., Adjei, A.A., Gyasi, R.K., Rodney, P., Ndjakani, Y., Anderson, W.A., Lucchi, N.W., Stiles, J.K., 2011. Intermittent Preventive Treatment with Sulfadoxine-Pyrimethamine against Malaria and Anemia in Pregnant Women. Am. J. Trop. Med. Hyg. 85, 12-21. https://doi.org/10.4269/ajtmh.2011.10-0512

Wini, L., Appleyard, B., Bobogare, A., Pikacha, J., 2013. Intermittent preventive treatment with sulfadoxine-pyrimethamine versus weekly chloroquine prophylaxis for malaria in pregnancy in Honiara, Solomon Islands: Malariaworld J. 4, 1-9.

Yoah, A.T., Fru-Cho, J., Kah, E., Njukang, E., Wirsiy, F.S., Duamor, C.T., Nkuo-Akenji, T., 
medRxiv preprint doi: https://doi.org/10.1101/2021.08.12.21261986; this version posted August 13, 2021. The copyright holder for this preprint (which was not certified by peer review) is the author/funder, who has granted medRxiv a license to display the preprint in perpetuity.

It is made available under a CC-BY-NC 4.0 International license .

2018. Impact of Adherence to a Full Course of Intermittent Preventive Treatment of

Malaria in Pregnancy on Pregnancy Outcome in Muyuka Health District $\square$ : A Cross-

Sectional Study. Int. Arch. Public Heal. Community Med. 2. 